\title{
Reproductive biology of the commercially exploited kolibri shrimp, Solenocera agassizii (Decapoda: Solenoceridae), from the Pacific coast of Costa Rica, with considerations for its management
}

\author{
Fresia Villalobos-Rojas ${ }^{1, *}$ \& Ingo S. Wehrtmann ${ }^{1,2}$ \\ 1. Unidad de Investigación Pesquera y Acuicultura (UNIP) of the Centro de Investigación en Ciencias Marinas y \\ Limnología (CIMAR), Universidad de Costa Rica; v.fresia@gmail.com \\ 2. Escuela de Biología, Universidad de Costa Rica, 2060 San José, Costa Rica; ingo.wehrtmann@ucr.ac.cr
}

\author{
Received 12-VII-2017. Corrected 29-VIII-2017. Accepted 03-I-2018.
}

\begin{abstract}
Shrimp trawling is the main deepwater fishery in Costa Rica, where Solenocera agassizii Faxon, 1893 has represented up to $30 \%$ of total shrimp landings for the Pacific coast. Despite the species' economic importance, knowledge about its biology is limited, hindering the development of an appropriate management plan for a sustainable extraction of this resource. The goals of this study were to estimate the size at onset of maturity (SOM) and to describe the reproductive dynamics of S. agassizii in order to provide information that will help to establish a minimum legal landing size and a possible fishing closure during its reproductive period. A total of 4 273 specimens (2 175 females: 2098 males) were analyzed between January 2007 and January 2008. The overall average size was $30.8 \mathrm{~mm} \mathrm{CL}$ (carapace length), with females larger $(32.4 \pm 5.7 \mathrm{~mm} \mathrm{CL})$ than males $(29.1 \pm 4.0$ $\mathrm{mm} \mathrm{CL}$ ). SOM was estimated with a logistic regression for females (SPM: size at physiological maturity) and as the breakpoint in the CL-TL (total length) regression for both sexes (SMM: size at morphological maturity). Males reached the SMM at a larger size $(32.4 \mathrm{~mm} \mathrm{CL})$ than females $(30.3 \mathrm{~mm} \mathrm{CL})$, whereas the SPM for females was $37.8 \mathrm{~mm} \mathrm{CL}$. The percentages of specimens caught below the estimated SMM were $77.4 \%$ (males) and $52.1 \%$ (females), whereas $79.2 \%$ of the females were below the estimated SPM. Mature females were obtained on a monthly basis, indicating a continuous reproduction of $S$. agassizii with peaks between July and October. These peaks coincide with months with high precipitation and coastal upwelling. In 2013, Costa Rica prohibited the granting of new commercial shrimp trawl licenses, as well as the renewal of existing licenses. Consequently, unless the sustainability of this fishery is scientifically proven, all existing licenses will expire in 2018. The results of this study indicate that the current fishery of $S$. agassizii in the Pacific coast of Costa Rica is not sustainable. Hence, the assessment of mesh selectivity for this fishery - to ascertain catches were the average size caught is equal to or greater than the SOM - is urgent, as well as the establishment of a MLS of $112.6 \mathrm{~mm}$ TL $(37.8 \mathrm{~mm} \mathrm{CL})$ and a fishing closure period in June and July. These recommendations aim to protect the spawning population and immature individuals of $S$. agassizii. Nevertheless, it is recommended to study the viability of employing alternative fishing gears to reduce the percentage of immature individuals captured and to avoid an overexploitation of the resource. Rev. Biol. Trop. 66(Suppl. 1): S92-S107. Epub 2018 April 01.
\end{abstract}

Key words: Deep-water fishery, trawl, reproduction, size at onset of sexual maturity, Eastern Tropical Pacific.

Fishery catches of shallow water resources have been declining worldwide, mainly as a result of technological development, market demands and overexploitation (Food and Agriculture Organization of the United Nations [FAO], 2001; Jackson et al., 2001; RamírezLlodra et al., 2011). As a consequence, commercial fleets started to exploit deepwater resources (FAO, 2001; Morato, Watson, Pitcher,
\& Pauly, 2006), and fisheries of the Pacific of Latin America are not an exception to this trend (Pauly et al., 2002; Hilborn et al., 2003; Arana, Alvarez-Perez, \& Pezzuto, 2009; Norse et al., 2012). Additionally, the absence of life history information of the exploited deepwater species is a major limitation for the development and implementation of adequate management measures (Polidoro et al., 2008). 
In Costa Rica, commercial fishing activities are concentrated along the Pacific coast (Wehrtmann \& Nielsen-Muñoz, 2009; Trujillo, Cisneros-Montemayor, Harper, \& Zeller, 2012). The Costa Rican deepwater fisheries focus primarily on shrimp trawling, where the target species are two pandalid shrimp species (Heterocarpus affinis Faxon, 1895, Heterocarpus vicarius Faxon, 1895) and the solenocerid species Solenocera agassizii Faxon, 1893 (Wehrtmann \& Echeverría-Sáenz, 2007; Wehrtmann \& Nielsen-Muñoz, 2009; Arana, Wehrtmann, Orellana, Nielsen-Muñoz, \& Villalobos-Rojas, 2013). The latter species, locally called "camarón fidel", is distributed along the Eastern Tropical Pacific from Nicaragua to Peru, can be found at depths between 16 and $350 \mathrm{~m}$ (Holthuis, 1980; Hendrickx, 1995) and is targeted in the commercial fisheries of Costa Rica, Panama and Colombia (Puentes, Madrid, \& Zapata, 2007; Wehrtmann \& Nielsen-Muñoz, 2009; Álvarez \& Ross-Salazar, 2010; Rodríguez, Rueda, \& Cubillos, 2012; Arana et al., 2013). This species represented up to $30 \%$ of the total shrimp landings of Costa Rica between 2001 and 2006, with the highest yearly landings in $1986\left(2.6 \times 10^{6} \mathrm{~kg}\right)$ (Wehrtmann \& Nielsen-Muñoz, 2009) followed by a continued reduction since $2005\left(0.57 \times 10^{6} \mathrm{~kg}\right)$ to roughly $0.0061 \times 10^{6} \mathrm{~kg}$ in 2014 (Instituto Costarricense de Pesca y Acuicultura [INCOPESCA]). Despite this alarming situation and the economic importance of this species, the knowledge about the biology of $S$. agassizii is rather limited (Villalobos-Rojas \& Wehrtmann, 2011; Rodríguez et al., 2012; Villalobos-Rojas \& Wehrtmann, 2014). Such a scenario hinders any effort to develop an appropriate management plan for the sustainable exploitation of this resource.

Basic biologic information, such as size at the onset of maturity (SOM) of a commercial species is essential for fisheries management (Li, Cheung \& Li, 2012; Queirós, Weetman, McLay, \& Dobby, 2013). Such data are needed for the estimation of the size of the spawning stocks, and provide the necessary information to set a minimum legal landing size, which aims to protect the reproductive potential of exploited populations (McQuaid, Briggs, \& Roberts, 2006). Several techniques are used to determine SOM in decapods. Histology is typically used to determine the size at physiological maturity (SPM) through the analysis of primary sexual characters, where microscopic changes in gonad tissues are associated with macroscopic gonad development (McQuaid et al., 2006; $\mathrm{Li}$ et al., 2012). In addition to the fact that the determination of SPM is not a trivial process, physiologically mature individuals may not be functionally able to mate due to small body size or the underdevelopment of body parts (sexual secondary characters) that are engaged in the mating process (McQuaid et al., 2006; PardalSouza, \& Pinheiro, 2013: Queirós et al., 2013). Therefore, the examination of the primary sexual characters alone could lead to an imprecise estimation of SOM (Bell, Redant, \&Tuck, 2006; MacDiarmid \& Saint-Marie, 2006). The assessment of the size at morphological maturity (SMM) is another technique used to determine SOM. Here the SMM is determined by an analysis of changes in the relative growth rate (allometry) between dimensions of different body structures throughout development (Claverie \& Smith, 2009; Segura \& Delgado, 2012; Pardal-Souza \& Pinheiro, 2013; Queirós et al., 2013). Finally, the presence of spermatophores attached to females can also be used to identify functionally mature individuals and determine SMM (Tirmizi, 1958; Segura \& Delgado, 2012).

The description of reproductive dynamics and the protection of the main spawning periods of commercially exploited penaeoid resources are essential for the development of proper management strategies. This information is used to protect the reproductive period and the reproductive areas of many exploited decapod resources (García \& Le Reste, 1986; Aragón-Noriega \& Alcantara-Razo, 2005; King, 2007). No specific regulations have been established for the $S$. agassizii fishery taking place along the Pacific coast of Costa Rica. Nevertheless, considering the negative effects of the shrimp bottom trawling fisheries on the 
Costa Rican environment and the marine fauna, in 2013 the renewal of current commercial shrimp trawl licenses, as well as the granting of new commercial shrimp trawl licenses was prohibited (Sala Constitucional, Sentencia No 2013-10540, 2013).

The main objective of the present study was to estimate SOM and to describe reproductive dynamics of $S$. agassizii in order to provide information, which may contribute to the development of sustainable management measures for the kolibri shrimp fishery along the Costa Rican Pacific coast.

\section{MATERIALS AND METHODS}

Specimens of $S$. agassizii were collected between January 2007 and January 2008 at depths ranging from 150 to $295 \mathrm{~m}$ along the central and southern Pacific coast of Costa Rica (Fig. 1). These samples were obtained with commercial shrimp trawlers $(22.5 \mathrm{~m}$ in length, $270 \mathrm{hp}$ ) equipped with two standard epibenthic nets $(20.5 \mathrm{~m}$ long; mouth opening of $5.35 \times$ $0.85 \mathrm{~m}$; mesh size $4.5 \mathrm{~cm}$; cod-end mesh size $3.0 \mathrm{~cm})$; average sampling duration was 20 min. at a speed of 2.0 knots $(\sim 3.7 \mathrm{~km} \mathrm{~h}-1)$.

Shrimps were sexed according to the presence (males) or absence (females) of the petasma (Hendrickx, 1995). For each specimen, we measured the carapace length (CL: from inner edge of eye orbit to outer edge of carapace), abdominal length (AL: from first abdominal segment to tip of telson), and calculated total length $(\mathrm{TL}=\mathrm{CL}+\mathrm{AL})$. The weight of the cephalothorax (CW), abdomen (AW) and the entire individual (TW) was also determined. Females were categorized (mature and immature stage) by direct observation of the gonad tissue; they were considered mature if tissues presented a pink to a burgundy color (stages 2-4) (see Villalobos-Rojas \& Wehrtmann, 2011).

A Shapiro-Wilk test (Zar, 1999) was used to analyze the normality of the CL distribution of female and male $S$. agassizii (Hammer et al., 2001; Paschoal, Guimarães, \& Couto, 2016).

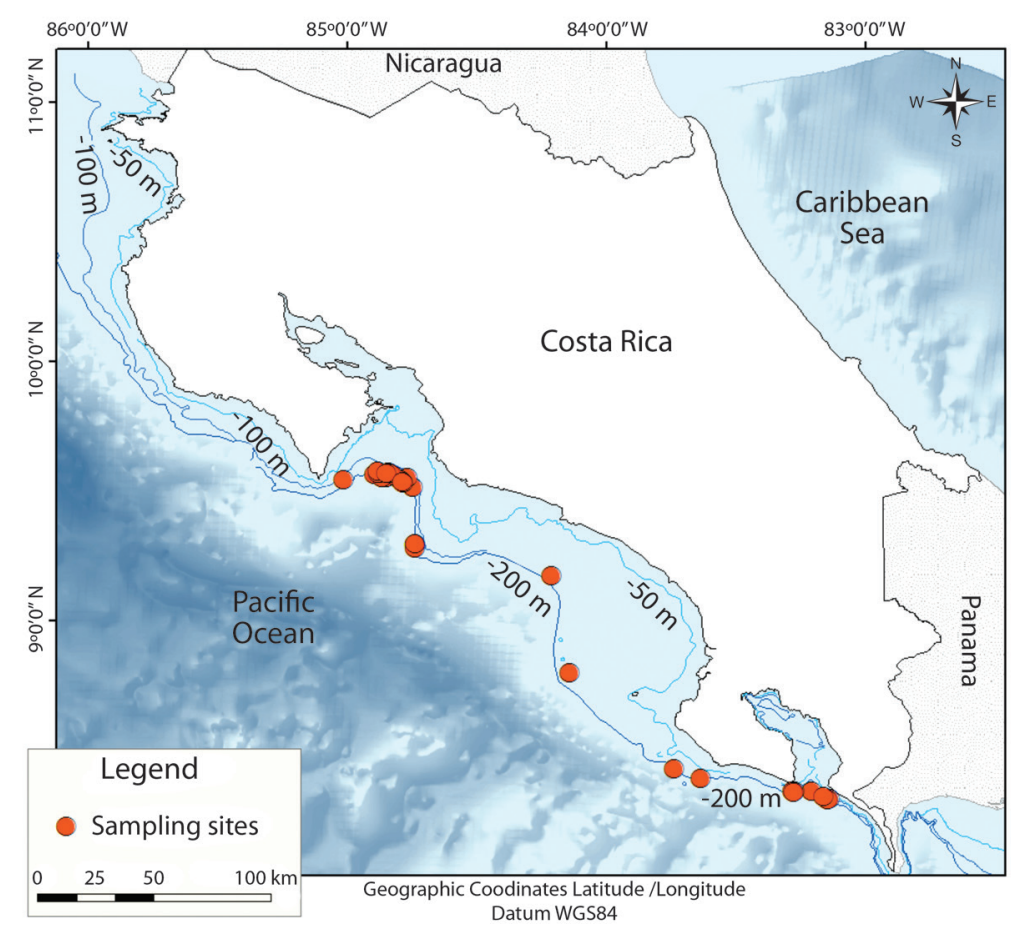

Fig. 1. Location of sampling sites of Solenocera agassizii along the Pacific coast of Costa Rica, 2007-2008. 
Differences in the size-frequency distributions of the population between the two sexes were determined by the Kolmogorov-Smirnov twosample test (Zar, 1999; Cha, Choi, \& Oh, 2004), and relationships between CL-TL and CL-CW were described through the allometric equation $\left(\mathrm{y}=\mathrm{ax}^{\mathrm{b}}\right)$ (Araújo, Negromonte, Barreto, \& Castiglioni, 2012). To test for differences between slopes of the linear regression of sexes (males and females), an analysis of covariance (ANCOVA; $\alpha=0.05$ ) was applied (Zar, 1999; Araújo et al., 2012). For each sex, the monthly mean CL variation throughout the sampling period was analyzed with an ANOVA $(\alpha=0.05)$ (Zar 1999; Xu, Yang, Abula, \& Qin, 2013). A Chi-square test for given probabilities (Zar, 1999) was conducted to detect CL ranges and months with sex ratios, which were different from the expected 1:1 (Hernáez, Rombenso, Pinheiro, \& Simões, 2012). Likewise, Chi-square tests were conducted to determine monthly variations in the ratio between mature (gonads in Stage II, III or IV) and immature females (gonads in Stage I). The relation between the percentage of mature females and mean CL for males and females was evaluated with a Spearman's rank correlation test.

Size at onset maturity was estimated by two methods: i) a logistic regression (SPM) (Roa, Ernst, \& Tapia, 1999, Segura \& Delgado, 2012) and ii) as the breakpoint in the CL-TL regression (SMM) (Segura \& Delgado 2012; Pardal-Souza \& Pinheiro 2013; Queirós et al., 2013). The SPM was determined only for females, based on the descriptions of the gonad maturity provided by Villalobos-Rojas \& Wehrtmann (2011), whereas the SMM was determined for both sexes. We considered the SPM as the CL at which $50 \%$ of females have mature gonads, and the SMM as the size at which the relationship between CL and TL has an allometric change in growth.

For the SPM, CL was considered as the explanatory variable, and the immature gonad (Stage I) or mature gonad (Stages II, III and IV) condition, coded as 0, 1 (binomial variable) was considered as the response variable. The logistic regression adjusts the maturity curve by applying a binomial function, which considers the point of maximum likelihood of the data within the model, using the following equation (Campos, Dumont, D'Incao, \& Branco, 2009; Rodríguez et al., 2012):

$$
p=\frac{1}{1+e^{(a+b * C L)}}
$$

where $p$ is the proportion of mature females, $b$ the slope, $a$ the intercept, and $C L$ the individual CL. The parameters and confidence intervals (CI $95 \%$ ) of the CL at which a female has a $50 \%$ probability of being mature (CL50 \%) were estimated using a Monte Carlo simulation (Roa et al. 1999; Rodríguez et al. 2012; Segura \& Delgado, 2012). The SPM was estimated as $-a / b$.

For the determination of the SMM, the segmented ('broken-line') linear model $((\log (\mathrm{TL})$ $=\mathrm{a}+\mathrm{b} \log (\mathrm{CL}))$ was used, by means of the 'segmented' library (Muggeo, 2008) available in the ' $\mathrm{R}$ Version 2.13.0' environment (R Development Core Team, 2014) (Muggeo 2008; Pardal-Souza, \& Pinheiro, 2013; Queirós et al., 2013). This method subdivides the data repetitively into two CL-delimited subsets and detects a transition point, $\mathrm{TP}\left(\mathrm{CL}_{\mathrm{I}}<\mathrm{TP}\right.$ and CLII > TP), where $\mathrm{CL}_{\mathrm{I}}$ and $\mathrm{CL}_{\mathrm{II}}$ represent females below and above the SMM, respectively. The resulting segments were evaluated using the Davies test of the 'difference in slope' parameter, which tests the hypothesis that the slopes of the regression lines to both sides of a given TP are the same (Muggeo, 2008).

\section{RESULTS}

A total of 4273 specimens $(2,175$ females; $50.9 \%$ of total: 2,098 males; $49.1 \%$ ) were collected during a sampling period of 13 months (January 2007-January 2008). Females were on average significantly larger (32.4 \pm 5.7 $\mathrm{mm}$ CL) than males $(29.1 \pm 4.0 \mathrm{~mm} \mathrm{CL})$ $(\mathrm{D}=0.3218 ; \mathrm{p}<0.001)$, with an overall size range of 17.0 - $53.5 \mathrm{~mm} \mathrm{CL} \mathrm{(56.9} \mathrm{-} 153.5 \mathrm{~mm}$ TL) for both sexes (Fig. 2). The size values at percentiles 25 and 75 for males were $26.6 \mathrm{~cm}$ and $31.8 \mathrm{~cm}$, respectively, while for females 


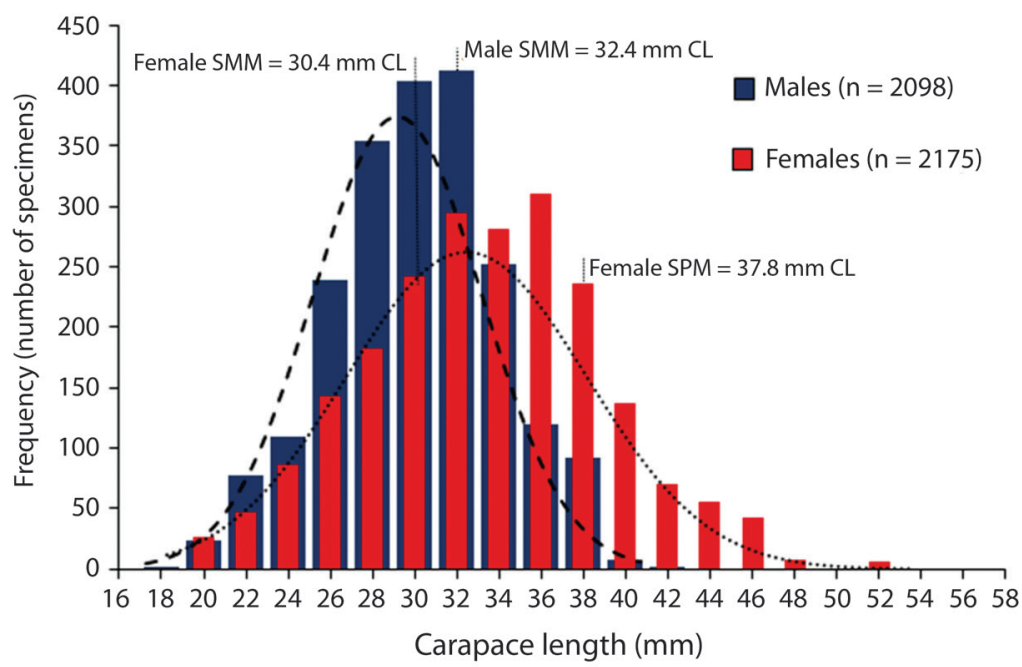

Fig. 2. Size-frequency distribution of males and females of Solenocera agassizii obtained along the Pacific coast of Costa Rica, 2007-2008. Dotted lines indicate the normal distribution for each sex (black: males; gray: females). SPM: Size at physiological maturity, SMM: Size at morphological maturity.

the size for these percentiles were $28.6 \mathrm{~cm}$ and $36.2 \mathrm{~cm} \mathrm{CL}$, respectively (Fig. 2). The CL-TL and CL-CW relationships were best described by a positive power equation. Female size exhibited higher weight increments with size than males $(p<0.001)$ (Fig. 3). The CL-TL presented a positive isometric growth for females $(0.90>b<1.10)$, whereas the CL-CW showed a positive allometric growth $(b>3.0)$ with $b$ being the slope (Fig. 3).

Although the overall sex ratio for the total population of $S$. agassizii was close to 1:1, it varied within CL size classes (Fig. 4): males represented more than $50 \%$ in most size classes below $30.0 \mathrm{~mm} \mathrm{CL}(\mathrm{p}<0.05)$, whereas females predominated in size classes over 36.0 mm CL (p < 0.05) (Fig. 4).

Monthly mean CL varied within the sampling period for females $(\mathrm{F}=16.11 ; \mathrm{p}<0.001)$ and males $(\mathrm{F}=80.49 ; \mathrm{p}<0.001)$, with a range of 29.97-35.54 mm CL for females and 26.51$32.11 \mathrm{~mm} \mathrm{CL}$ for males (Figs. 5C and D). The sex ratio also varied within months $(\mathrm{p}<0.01)$ (Fig 5). Most months presented the expected ratio (1:1), however, in February and May 2007 more females than males were encountered, and in December 2007 more males than females were present $(\mathrm{p}<0.05)$ (Fig. 5). Mature females were found during all months of the sampling period; nevertheless, the percentage of females varied within the sampling months ( $<<0.001)$ : January 2007 June, July, August and October 2007 were months with a high percentage $(\sim 30 \%)$ of mature females (Fig. 5B). Months with the highest number of mature females presented higher female mean $\mathrm{CL}$ values (rho $=0.63 ; \mathrm{p}<0.05$ ), whereas no significant relation was detected between the frequencies of mature females and mean male $\mathrm{CL}(\mathrm{rho}=0.46 ; \mathrm{p}>0.05)$.

Males of $S$. agassizii reached the SMM at a higher CL value (CL: $32.4 \mathrm{~mm}$ ) than females (CL: $30.3 \mathrm{~mm}$ ) (Fig. 6, Table 1). The percentage of specimens caught below the SMM was $77.4 \%$ (males) and $52.1 \%$ (females). For both sexes, the CL-TL relationships for immature and mature individuals were significant $(\mathrm{p}>$ $0.001)$ and presented high correlations $\left(\mathrm{r}^{2}>\right.$ 0.8) (Fig. 6). Females with immature gonads (mean $30.6 \mathrm{~mm} \mathrm{CL}$ ) were substantially smaller than females with mature gonads (mean 38.1 $\mathrm{mm} \mathrm{CL}$ ), with size ranges of $17.9-46.8 \mathrm{~mm}$ $\mathrm{CL}$ and $28-51 \mathrm{~mm} \mathrm{CL}$, respectively. The SPM for females was $37.8 \mathrm{~mm} \mathrm{CL}$ (Fig. 7, Table 1), 

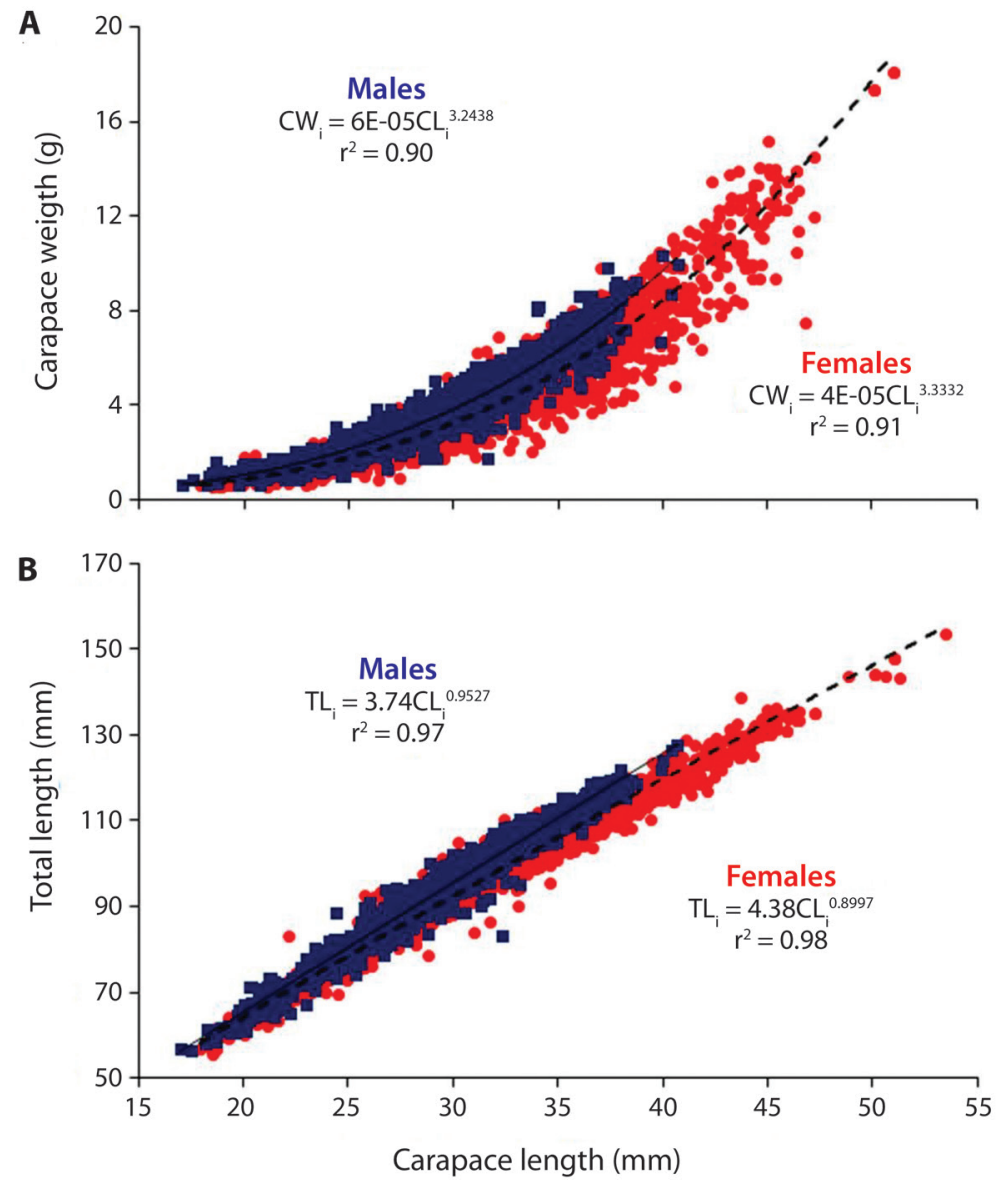

Fig. 3. Solenocera agassizii from the Pacific coast of Costa Rica: relationship between (A) carapace length (CL) vs carapace weight (CW), and (B) carapace length (CL) vs total length (TL) for males (squares) and females (circles); n = 4273.

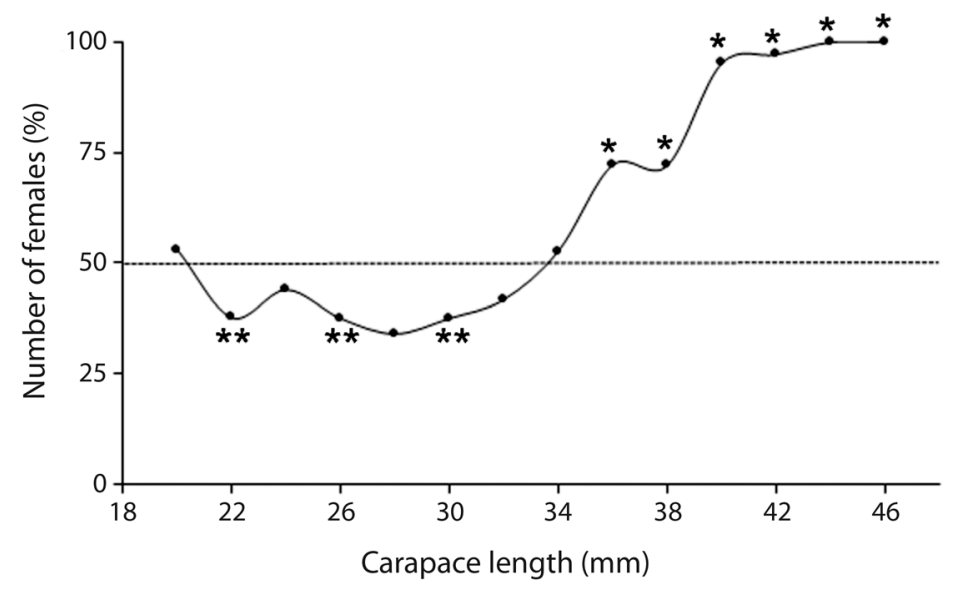

Fig. 4. Changes in number of females (\%) of Solenocera agassizii from the Pacific coast of Costa Rica in relation to carapace length size classes. Only size classes with more than 30 specimens were considered $(n=4273)$. Dotted line represents sex ratio of 1:1. *Females $>$ Males $(\mathrm{p}<0.01)$ and $* *$ Males $>$ Females $(\mathrm{p}<0.01)$. 

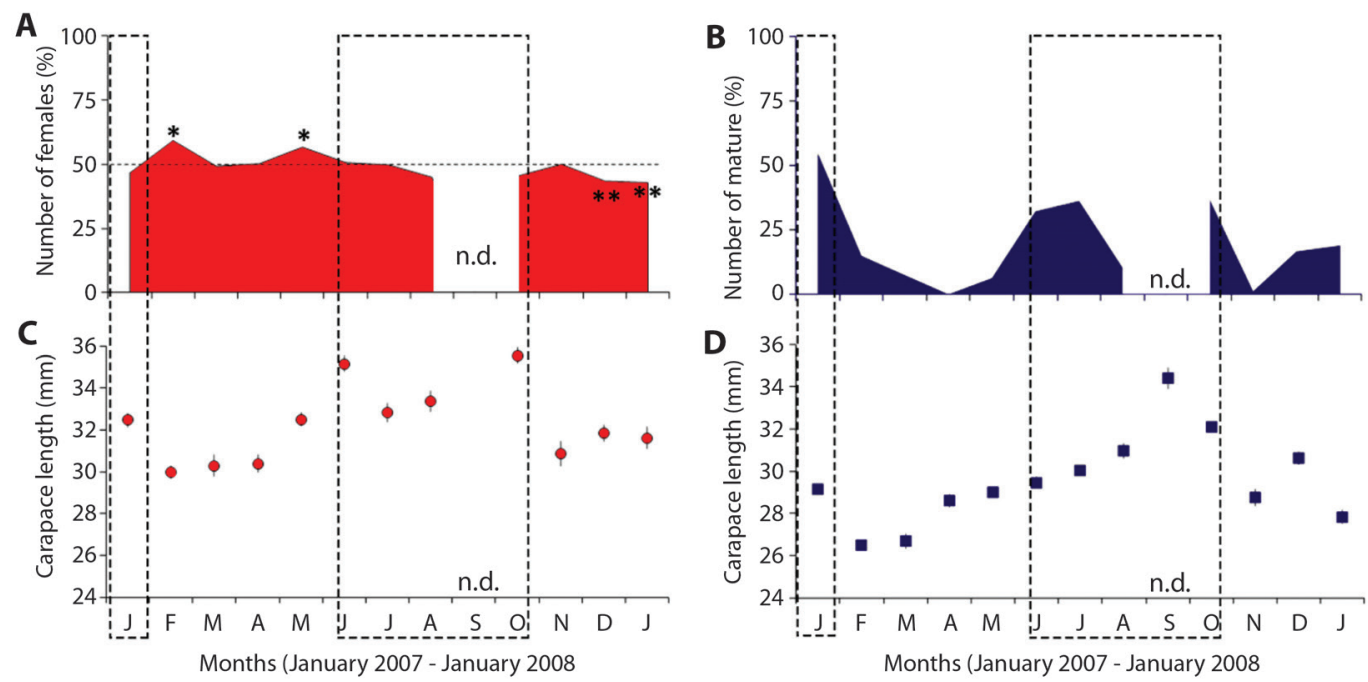

Fig. 5. Monthly variation of Solenocera agassizii from the Pacific coast of Costa Rica (January 2007 to January 2008). A: Female frequency (\%); B: mature female frequency; C: female carapace length (average CL \pm standard error); D: male carapace length (average $\mathrm{CL} \pm$ standard error). ${ }^{*}$ Females $>$ Males $(\mathrm{p}<0.01)$ and $* *$ Males $>$ Females $(\mathrm{p}<0.01)$, n.d.: No data; $\mathrm{n}=4$ 273. Dotted line represents sex ratio of $1: 1$, dotted box indicates reproductive peaks.

TABLE 1

Size at sexual maturity for Solenocera agassizii from the Pacific coast of Costa Rica, 2007-2008

\begin{tabular}{lcccc} 
& \multicolumn{2}{c}{ Size at morphological maturity $(\mathrm{mm})$} & \multicolumn{2}{c}{ Size at physiological maturity $(\mathrm{mm})$} \\
& Carapace length (CI, 95 \%) & Total length (CI, 95\%) & Carapace length (CI, 95 \%) & Total length (CI, 95\%) \\
Females & $30.4(29.8-31.5)$ & $94.3(92.7-97.2)$ & $37.8(37.4-38.2)$ & $113.5(112.5-114.5)$ \\
Males & $32.4(31.1-33.9)$ & $103.1(99.6-107.3)$ & n.c. & n.c. \\
\hline
\end{tabular}

CI, $95 \%$ : confidence intervals at $95 \%$; n.c.: not calculated.

and $79.2 \%$ of all females analyzed were below this SPM. The corresponding total lengths and $95 \%$ confidence intervals for the SMM and SPM are summarized in Table 1. The SOM estimated for the population of $S$. agassizii was $37.8 \mathrm{~mm}$ CL (112.6 mm TL). In contrast, the average size of all analyzed individuals was 30.8 mm CL (96.07 mm TL) (Fig. 7).

\section{DISCUSION}

While previous studies in Central America regarding $S$. agassizii provided a general description of the fishery (Wehrtmann \& Nielsen-Muñoz, 2009; Wehrtmann, Arana, Barriga, Gracia, \& Pezzuto, 2012) and of its sexual characters, spermatophores and gonad development (Villalobos \& Wehrtmann, 2011, 2014), here we report for the first time the SOM and seasonal reproductive patterns of $S$. agassizii. Such information is urgently needed for the development of adequate management measures (see King, 2007), especially considering that the results of the study revealed that a high percentage (79\%) of the specimens analyzed was comprised by individuals that have not reached sexual maturity.

The maximum sizes of the population of $S$. agassizii sampled in this study coincide with previous reports: $149 \mathrm{~mm}$ maximum TL (Holthuis, 1980), $140 \mathrm{~mm}$ maximum TL (Hendrickx, 1995), and 28-155 mm TL range (Rodríguez et al., 2012). When comparing our results with the maximum sizes reported for 

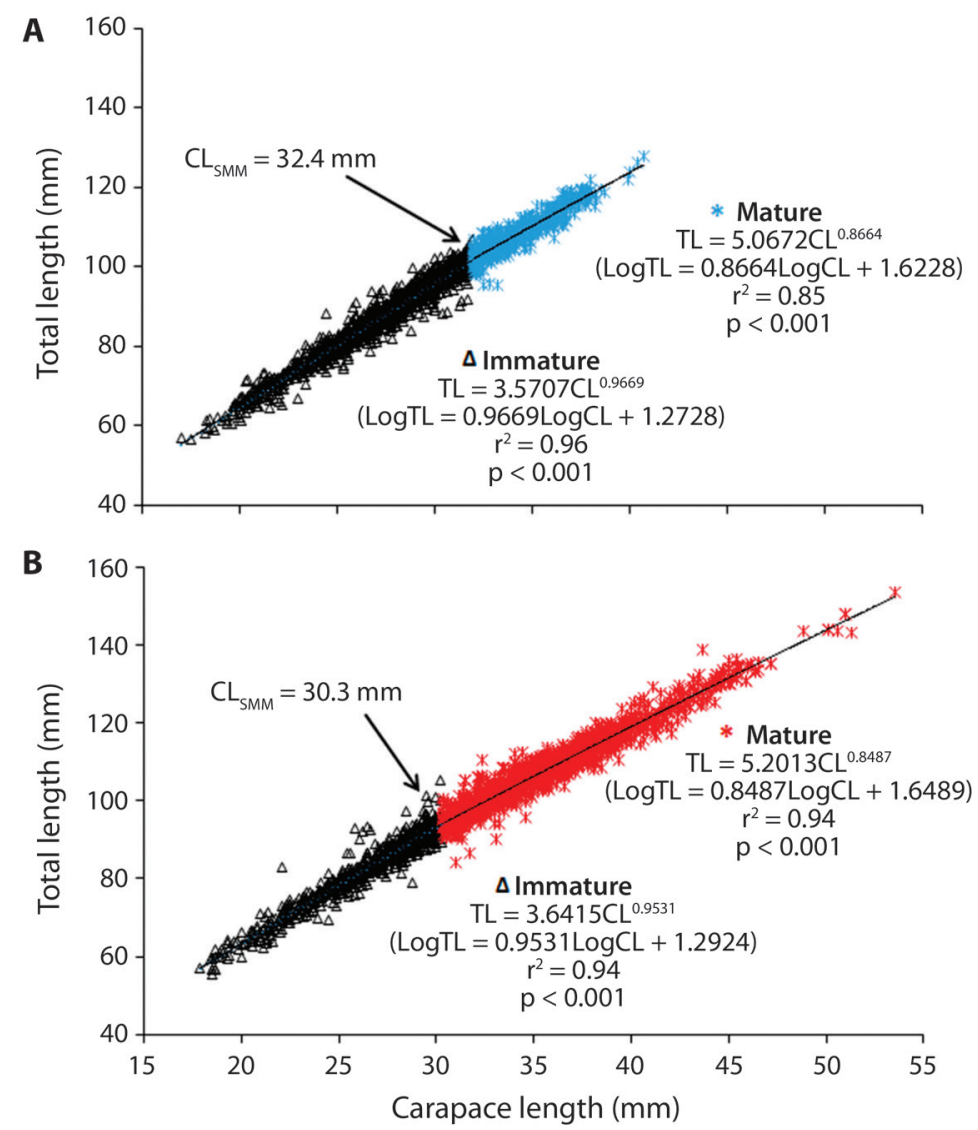

Fig. 6. Size at morphological maturity (SMM) for (A) males and (B) females of Solenocera agassizii collected along the Pacific coast of Costa Rica, 2007-2008. The arrows indicate $\mathrm{CL}_{\mathrm{SMM}}$ for each sex; $\mathrm{n}=4273$.

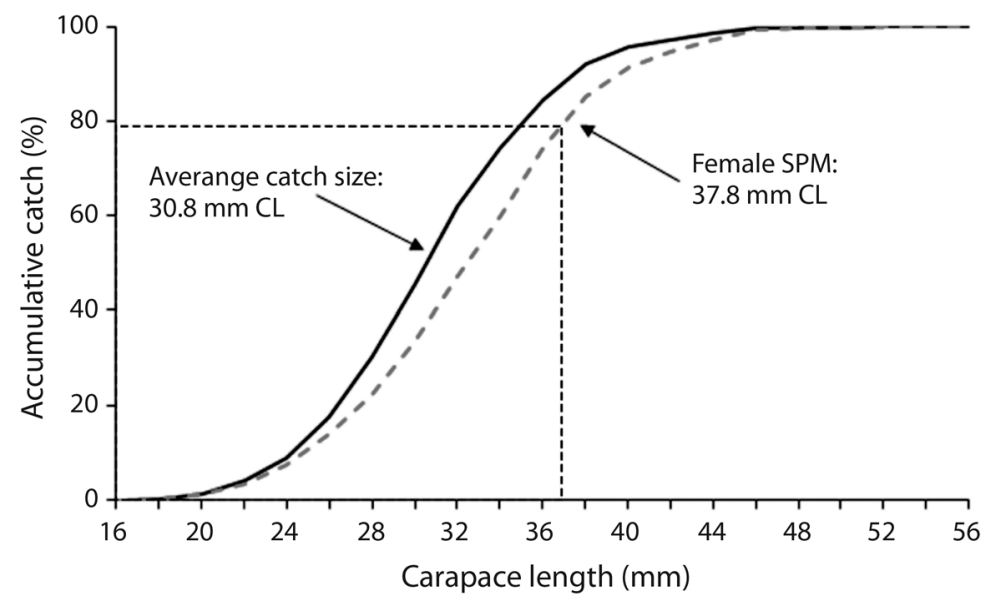

Fig. 7. Accumulative catch per size (\%) of total catch (black line) and female catch (gray dotted line) of Solenocera agassizii collected along the Pacific coast of Costa Rica, 2007-2008. The arrows indicate $\mathrm{CL}_{\mathrm{SPM}}$ calculated for females (right) and average size of total catch (left); $n=4$ 273. SPM: Size at physiological maturity. 
other Solenocera shrimp, S. agassizii is the largest species of this genus (Table 2).

The mean size differences found between females and males are a common trait in solenocerid species, where females are usually larger than males (Pérez-Farfante \& Bullis, 1973, Dineshbab \& Manissery, 2008; Li et al., 2012; Segura \& Delgado, 2012). The higher number of females than males in larger size classes observed in S. agassizii (Fig. 4) has also been observed in other solenocerid species (Solenocera melantho Ohtomi \& Irieda, 1997; Solenocera choprai Dineshbabu \& Manissery, 2008; Li et al., 2012). The main factors that affect this variation include differential longevity, mortality, migration behavior, and growth rates between females and males (Baelde, 1992). The sexual dimorphism in shrimps with larger females is typically explained by the positive relationship between body size and fecundity, which plays an important role in the reproduction of crustacean decapods. The energy investment required to produce larger body sizes in female penaeoid shrimps has been shown to be beneficial, as larger females produce more oocytes (Ramírez-Llodra, 2002; Sobrino \& García, 2007). This makes females commercially more important than males for the fishery due to their larger sizes.

The positive allometric growth relationship between CL and CW detected for both females and males of $S$. agassizii indicates a

TABLE 2

Maximum carapace length (CL) reported for species of the genus Solenocera

\begin{tabular}{|c|c|c|c|}
\hline Species & Maximum size & Distribution & Reference \\
\hline Solenocera acuminata Pérez Farfante \& Bullis, 1973 & $39.5 \mathrm{~mm} \mathrm{CL}$ & Western Altantic & Pérez-Farfante \& Bullis (1973) \\
\hline Solenocera africana Stebbing, 1917 & $25.4 \mathrm{~mm} \mathrm{CL}$ & Southeast Africa & Freitas (1985) \\
\hline Solenocera agassizii Faxon, 1893 & $\begin{array}{l}53.5 \mathrm{~mm} \mathrm{CL} \\
153.5 \mathrm{~mm} \mathrm{LT}\end{array}$ & Eastern Tropical Pacific & Present study \\
\hline Solenocera alfonso Pérez Farfante, 1981 & $31.5 \mathrm{~mm} \mathrm{CL}$ & Philippine waters & Pérez-Farfante (1981) \\
\hline Solenocera algoensis Barnard, 1947 & $36.8 \mathrm{~mm} \mathrm{CL}$ & Southeast Africa & Freitas (1985) \\
\hline Solenocera atlantidis Burkenroad, 1939 & $18.5 \mathrm{~mm} \mathrm{CL}$ & Western Altantic & Pérez-Farfante \& Bullis (1973) \\
\hline Solenocera australiana Pérez Farfante \& Grey, 1980 & $42 \mathrm{~mm} \mathrm{CL}$ & Northern Australia & Pérez-Farfante \& Grey (1980) \\
\hline Solenocera choprai Nataraj, 1945 & $28.5 \mathrm{~mm} \mathrm{CL}$ & Indo-West Pacific & Holthuis (1980) \\
\hline Solenocera choprai Nataraj, 1945 & $32 \mathrm{~mm} \mathrm{CL}$ & Southeast Africa & Freitas (1985) \\
\hline $\begin{array}{l}\text { Solenocera crassicornis (H. Milne Edwards, } 1837 \\
\text { [in Milne Edwards, 1834-1840]) }\end{array}$ & $140 \mathrm{~mm} \mathrm{TL}$ & Indo-West Pacific & Holthuis (1980) \\
\hline Solenocera florea Burkenroad, 1938 & $80 \mathrm{~mm} \mathrm{TL}$ & Eastern Pacific & Hendrickx (1995) \\
\hline Solenocera geijskesi Holthuis, 1959 & $17 \mathrm{~mm} \mathrm{CL}$ & Western Altantic & Pérez-Farfante \& Bullis (1973) \\
\hline Solenocera hextii Wood-Mason \& Alcock, 1981 & $20 \mathrm{~mm} \mathrm{CL}$ & Indo-West Pacific & Holthuis (1980) \\
\hline Solenocera koelbeli de Man, 1911 & $22 \mathrm{~mm} \mathrm{CL}$ & Indo-West Pacific & Holthuis (1980) \\
\hline Solenocera melantho de Man, 1907 & $45.9 \mathrm{~mm} \mathrm{CL}$ & Indo-West Pacific & $\begin{array}{l}\text { Ohtomi, Yamamoto, } \\
\text { \& Koshio (1998) }\end{array}$ \\
\hline Solenocera membranacea (Risso, 1816) & $30 \mathrm{~mm} \mathrm{CL}$ & Eastern Pacific & Demestre \& Fortuno (1992) \\
\hline Solenocera mutator Burkenroad, 1938 & $90 \mathrm{~mm} \mathrm{TL}$ & Eastern Pacific & Hendrickx (1995) \\
\hline Solenocera necopina Burkenroad, 1939 & $27 \mathrm{~mm} \mathrm{CL}$ & Western Altantic & Pérez-Farfante \& Bullis (1973) \\
\hline Solenocera pectinata (Spence Bate, 1888) & $16 \mathrm{~mm} \mathrm{CL}$ & Indo-West Pacific & Holthuis (1980) \\
\hline Solenocera vioscai Burkenroad, 1934 & $31 \mathrm{~mm} \mathrm{CL}$ & Western Altantic & Pérez-Farfante \& Bullis (1973) \\
\hline Solenocera waltairensis M.J. George \& Muthu, 1970 & $17 \mathrm{~mm} \mathrm{CL}$ & Indian waters & George \& Muthu (1968) \\
\hline
\end{tabular}


proportionally higher increase in weight with increasing length, which is consistent with observations on the growth of other decapods (Díaz, Petriella, \& Fenucci, 2003; Harán, Mallo, \& Fenucci, 2004; Branco, 2005; Li et al., 2012). Female and male penaeid shrimp typically tend to increase more in body weight than in body size, after attaining recruitment size to the fishery (Ohtomi \& Irieda, 1997). The higher weight increments with size found in females $(b=3.33)$ than in males $(b=3.24)$ disagrees with studies on some solenocerid shrimps (Pleoticus muelleri: see Segura \& Delgado, 2012, Haliporoides sibogae: see Baelde, 1994), but coincides with results obtained for S. melantho (see Li et al., 2012). The values obtained for the allometric coefficient (b) in this study were higher than the reported for other solenocerid shrimp (H. sibogae: see Baelde, 1994, S. melantho: see Li et al., 2012, and P. muelleri: see Segura \& Delgado, 2012), and are similar to those found for penaeid shrimp (close to 3) (Franco, Ferreira, \& Nobre, 2006, Li et al., 2012, Segura \& Delgado, 2012, Gautam, Nazar, Anand-Ganesh, Mahendran, \& Mahadevan, 2014), indicating that S. agassizii shrimp become corpulent as they increase in length.

The presence of mature females in all stages of gonadal development throughout the sampling period (January 2007 - January 2008) suggests a continuous reproduction of $S$. agassizii along the Pacific coast of Costa Rica. Similar reproductive patterns have been described for many decapod shrimp species from tropical and subtropical regions, including $S$. choprai (see Dineshbabu \& Manissery, 2008), Artemesia longinaris (see Castilho, Costa, Fransozo, \& Boschi, 2007), Sicyonia dorsalis (see Castilho, Furlan, Costa, \& Fransozo, 2008), Trachypenaeus byrdi (see Hernández-Noguera, Soto-Rojas, \& Canales-Ramirez, 2016) and Penaeus stylirostris and Penaeus occidentalis (see Tabash \& Palacios, 1996). Despite the absence of a marked seasonal pattern, reproductive peaks were observed between June and October (no data for September) and in January; during these periods $\geq 30 \%$ of females were mature or maturing (Fig. 5B). From 2005 to 2011, S. agassizii showed at least two spawning peaks per year, one from May through July and the other during December-January (F. Villalobos-Rojas, unpublished data). This is consistent with other findings, where penaeid shrimps also showed two spawning peaks per year (Metapenaeus ensis (De Haan, 1844 [in De Haan, 1833-1850]): see Chu, Tam, Chung, \& Ng, 1993, Farfantepenaeus californiensis (Holmes, 1900): see Leal-Gaxiola, López-Martínez, Chávez, Hernández-Vázquez, \& Méndez-Tenorio, 2001, Penaeus notialis Pérez Farfante, 1967: see Paramo, Pérez, \& Wolff, 2014). The presence of peaks with higher reproductive intensity at certain times of the year has been associated with changes in water temperature, water salinity and food availability (Aragón-Noriega, \& Alcantara-Razo, 2005, López-Martínez et al., 2005; Castilho et al., 2008; Hernáez et al., 2012; Castilho et al., 2015). Months with higher temperatures can positively affect reproduction by accelerating the metabolism, which in turn affects directly spawning, gonadal maturation or both (Costa \& Franzoso, 2004; López-Martínez et al., 2005; Castilho et al., 2015). Moreover, a decrease in salinity during the rainy season was suggested to serve as a triggering factor for the onset of ovarian development (Hernáez et al., 2012). Furthermore, the increase of chlorophyll content in seawater or the presence of coastal upwelling has been associated with the increase in the availability of food for shrimp larvae (Costa \& Franzoso, 2004, Aragón-Noriega \& Alcantara-Razo, 2005, Castilho et al., 2008). In the present study, we assume that the variation in reproductive intensity of $S$. agassizii is mainly due to two environmental factors: (1) the presence of a peak in June-July may be attributed to increased precipitation, which causes a decrease in salinity and an increase of food availability from the river discharge (Palter, León-Coto, \& Ballestero, 2007). A relationship between chlorophyll $a$ concentration and species reproduction has been reported for other exploited shrimp species in the Gulf of Nicoya, Costa Rica (Alfaro, Palacios, Aldave, 
\& Angulo, 1993, Tabash-Blanco, 2007). (2) The peak encountered in December-January may be related to the seasonal coastal upwelling event reported for the northern Pacific coast of Costa Rica (Alfaro \& Cortés, 2012, Stuhldreier et al., 2015), which increases the food availability and thus provides favorable conditions for reproduction.

Segura \& Delgado (2012) concluded that physiological (SMM) and morphological maturity (SOM) occurred at similar sizes in $P$. muelleri (Bate, 1888). In the present study, the single use of SMM was not adequate to determine SOM because SMM was smaller than SPM (Table 1). This conclusion is in agreement with similar findings in Penaeus merguiensis (De Man, 1988) (see Hoang, Lee, Keenan, \& Marsden, 2002), which reported that males of $P$. merguiensis reached the SMM at larger sizes than females (Fig. 6, Table 1). The same authors also suggested that the size of an individual is more decisive for the development of its sexual characters (e. g. thelycum) than age. Accordingly, the SMM obtained in the present study should coincide with the size at which the thelycum of $S$. agassizii is fully developed. This assumption is corroborated by the fact that SMM obtained in the present study coincides with the minimum size at which spermatophores were found attached to the thelycum (from $28.5 \mathrm{~mm} \mathrm{CL}$ ) (Villalobos-Rojas \& Wehrtmann, 2014).

The SOM estimated for S. agassizii in the present study resembles the SPM reported for the same species from the Colombian Pacific (Rodríguez et al., 2012). The estimation of the SOM is a fundamental aspect for any fishery regulation, because catch-size limits are required for the protection of immature individuals from exploitation; moreover, such a size limit is necessary to ensure the reproduction of a sufficient number of recruits to successfully maintain the population ( $\mathrm{Li}$ et al., 2012). Additionally, the establishment of size limits will allow the fishery to catch larger and heavier shrimps, which in turn will produce more and better quality of offspring (Birkeland \& Dayton, 2005, Butler, Macdiarmid, \& Gnanalingam,
2015). Therefore, and to guarantee that at least $50 \%$ of the individuals have an opportunity to reproduce, the average size should be equal to or greater than SOM (King, 2007). The present data, however, indicate that more than $75 \%$ of the females captured in trawls were immature $(<113.5 \mathrm{~mm}$ TL) ; moreover, the overall average size of $S$. agassizii caught in the present study was smaller than the SOM $(95.4<113.7$ $\mathrm{mm}$ TL), thus jeopardizing a successful reproduction of the $S$. agassizii population. Such a situation is usually related to a poor selectivity of trawling nets, which tend to maximize the capture of individuals that have not reached maturity (Carlucci, D’Onghia, Sion, Maiorano, \& Tursi, 2006; King 2007).

\section{Management recommendations for the Solenocera agassizii fishery of the Pacific coast of Costa Rica}

The management measures used in crustacean fisheries to ensure efficient and sustainable resource extraction are mainly fishing gear regulations, catch and effort restrictions, minimum legal landing size, as well as temporal and spatial fishing restrictions (closures) (King, 2007). Until now, no specific regulations have been established for the $S$. agassizii fishery taking place along the Pacific coast of Costa Rica. Considering the negative effects of the shrimp bottom trawl fisheries on the environment and marine fauna, Costa Rica prohibited the granting of new commercial shrimp trawl licenses, as well as the renewal of existing licenses in 2013 (Sala Constitucional, Sentencia No 201310540, 2013). With this prohibition, unless the sustainability of the shrimp bottom trawl fishery is scientifically proven, all existing licenses for this fishery will expire in 2018. Taking in account the results of this study, we consider that the current fishery of $S$. agassizii in the Pacific coast of Costa Rica is not sustainable. This conclusion is based on the high percentage of females collected below the SOM (> $75 \%$ ) and the fact that the average size of $S$. agassizii caught is smaller than SOM. Hence, the assessment of the mesh selectivity for this fishery, to 
ascertain catches were the average size caught is equal to or greater than the SOM is urgently needed. Coupled with mesh selectivity, we recommend the establishment of a minimum legal landing size of $112.6 \mathrm{~mm}$ TL $(37.8 \mathrm{~mm}$ $\mathrm{CL}$ ), as well as a fishing closure during a period of two months (June and July). These two recommendations aim to protect the spawning population and immature individuals of $S$. agassizii. Moreover, the viability of employing alternative fishing gears (e.g., traps) should be investigated. These studies and modifications are needed to reduce the percentage of immature individuals currently captured and to avoid a possible overexploitation of the resource. Furthermore, it is strongly recommended to establish a monitoring program for this fishery with the objective of evaluating the stock and determining the condition of exploitation of the resource.

\section{ACKNOWLEDGEMENTS}

This study was financially and logistically supported by the following institutions: Universidad de Costa Rica (UCR) (project V.I. no. 111-A4-508), Escuela de Biología of UCR, Ristic AG, Oberferrieden, Germany, and The Rainbow Jewels S.A., Puntarenas, Costa Rica. We appreciate the valuable collaboration of the captains and crews of the shrimp trawlers of the company The Rainbow Jewels S. A. We would like to thank all the "UNIPER@S" that have been part of the project and have helped us in the laboratory and field work: Muchísimas gracias. Finally, we would like to thank the two anonymous referees for their valuable comments, which improved the quality of our contribution.

\section{RESUMEN}

Biología reproductiva del camarón fidel, Solenocera agassizii (Decapoda: Solenoceridae), comercialmente explotado en la costa del Pacífico costarricense, con consideraciones para su manejo. La pesca de arrastre de camarón es la principal pesquería de aguas profundas costarricenses, donde Solenocera agassizii ha representado el $30 \%$ de las capturas de camarón en la costa del Pacífico.
A pesar de la importancia económica de la especie, el conocimiento sobre su biología es limitado, dificultando desarrollar un plan de manejo adecuado para la pesca sostenible de este recurso. La meta de este estudio fue contribuir al manejo sostenible de $S$. agassizii, mediante la estimación de la talla de madurez sexual (TMS) y la descripción de la dinámica reproductiva de la especie y por lo tanto proporcionar información que ayude a establecer una talla mínima legal de captura (TMLC) y una veda temporal de pesca durante su época reproductiva. Se midió un total de 4273 especímenes (2 175 hembras: 2098 machos) entre Enero de 2007 y Enero de 2008. La talla promedio general fue de $30.8 \mathrm{~mm}$ CL (longitud cefalotorácica), con hembras más grandes $(32.4 \pm 5.7 \mathrm{~mm} \mathrm{CL})$ que los machos $(29.1 \pm$ $4.0 \mathrm{~mm} \mathrm{CL}$ ). La TMS se estimó mediante: regresión logística para hembras (TMF, talla de madurez fisiológica) y el punto de inflexión de la regresión CL-TL (longitud total) para ambos sexos (TMM, talla de madurez morfológica). Las hembras alcanzaron la TMM (30.3 mm CL) antes que los machos (32.4 mm CL), mientras que la TMF para las hembras fue de $37.8 \mathrm{~mm} \mathrm{CL}$. Los porcentajes de especímenes capturados por debajo de la TMM estimada fueron: $77.4 \%$ (machos) y $52.1 \%$ (hembras), mientras que el 79.2 $\%$ de las hembras estaban por debajo de la TMF estimada. Las hembras maduras fueron encontradas mensualmente, indicando una reproducción continua, con picos reproductivos que coinciden con los meses de precipitaciones altas y afloramientos costeros (Julio-Octubre y Enero). En el 2013, Costa Rica prohibió la otorgación de nuevas licencias comerciales de arrastre de camarón y la renovación de licencias existentes. Por lo tanto, a menos de que se compruebe científicamente la sostenibilidad de esta pesquería, todas las licencias existentes expirarán en el 2018. Los resultados de este estudio, sugieren una pesquería no sostenible de $S$. agassizii en la costa pacífica costarricense. Por lo tanto, con el fin de proteger a la población reproductora así como a los individuos inmaduros de S. agassizii es urgente: la evaluación de la selectividad de la malla para esta pesquería (con el fin de obtener capturas con la TMLC igual o mayor que la SOM), el establecimiento de la TMLC a los $112.6 \mathrm{~mm}$ TL (37.8 $\mathrm{mm} \mathrm{CL})$ y de un periodo de veda en Junio y Julio. Además, es necesario estudiar la viabilidad de emplear artes de pesca alternativos para reducir el porcentaje de individuos inmaduros capturados y evitar la sobreexplotación del recurso.

Palabras clave: Talla de primera madurez sexual, Pesca de profundidad de arrastre, Pacífico Tropical Oriental.

\section{REFERENCES}

Alfaro, E. J., \& Cortés, J. (2012). Atmospheric forcing of cool subsurface water events in Bahía Culebra, Gulf of Papagayo, Costa Rica. Revista de Biología Tropical, 60(2), 173-186. 
Alfaro, J., Palacios, A., Aldave, T. M., \& Angulo, R. A. (1993). Reproducción del camarón Penaeus occidentalis (Decapoda: Penaeidae) en el Golfo de Nicoya, Costa Rica. Revista de Biología Tropical, 41(3), 563-572.

Álvarez, J., \& Ross-Salazar, E. (2010). La pesca de arrastre en Costa Rica. San José, Costa Rica: Fundación MarViva.

Aragón-Noriega, E. A., \& Alcántara-Razo, E. (2005). Influence of sea surface temperature on reproductive period and size at maturity of brown shrimp (Farfantepenaeus californiensis) in the Gulf of California. Marine Biology, 146, 373-379.

Arana, P. M., Alvarez-Perez, J., \& Pezzuto, P. R. (2009). Deep-sea fisheries off Latin America: an introduction. Latin American Journal of Aquatic Research, 37(3), 281-284. doi: 10.3856/vol37-issue3-fülltext-1

Arana P. M., Wehrtmann, I. S., Orellana, J. C., NielsenMuñoz, V., \& Villalobos-Rojas, F. (2013). By-catch associated with fisheries of Heterocarpus vicarius (Costa Rica) and Heterocarpus reedi (Chile) (Decapoda: Pandalidae): A six-year study (2004-2009) Journal of Crustacean Biology, 33(2), 198-209. doi: 10.1163/1937240X-00002123

Araújo, M. S. L. C., Negromonte, A. O., Barreto, A. V., \& Castiglioni, D. S. (2012). Sexual maturity of the swimming crab Callinectes danae (Crustacea: Portunidae) at the Santa Cruz Channel, a tropical coastal environment. Journal of the Marine Biological Association of the United Kingdom, 92(2), 287-293. doi:10.1017/S0025315411001135

Baelde, A. (1992). Reproductive biology of commercially exploited deep-water royal red prawns (Haliporoides sibogae, Solenoceridae) in south-east Australia. Marine Biology, 113, 447-456.

Baelde, P. (1994). Growth, mortality and yield-per-recruit of deep-water royal red prawns (Haliporoides sibogae) off eastern Australia using the length-based MULTIFAN method. Marine Biology, 118, 617-625.

Bell, M. C., Redant, F., \& Tuck, I. (2006). Nephrops species. In B. Phillips (Ed.). Lobsters: Biology, Management, Aquaculture and Fisheries (pp. 412461). Oxford, UK: Blackwell Publishing. doi: 10.1002/9780470995969.ch13

Birkeland, C., \& Dayton, P. K. (2005). The importance in fishery management of leaving the big ones. Trends in Ecology and Evolution, 20(7), 356-358. doi:10.1016/j.tree.2005.03.015

Branco, J. O. (2005). Biologia e pesca do camarão setebarbas Xiphopenaeus kroyeri (Heller) (Crustacea, Penaeidae), na Armação do Itapocoroy, Penha, Santa Catarina, Brasil. Revista Brasileira de Zoologia, 22(4), 1050-1062.
Butler, M. J., Macdiarmid, A., \& Gnanalingam, G. (2015) The effect of parental size on spermatophore production, egg quality, fertilization success, and larval characteristics in the Caribbean Spiny lobster, Panulirus argus. ICES Journal of Marine Science, 72(1), i115-i123. doi:10.1093/icesjms/fsv015

Campos, B. R., Dumont, L. F. C., D'Incao, F., \& Branco, J. O. (2009). Ovarian development and length at first maturity of sea-bob-shrimp Xiphopenaeus kroyeri (Heller) in southern Brazil based on histological analysis. Nauplius, 17, 9-12.

Carlucci, R., D’Onghia, G., Sion, L., Maiorano, P., \& Tursi, A. (2006). Selectivity parameters and size at first maturity in deep-water shrimps, Aristaeomorpha foliacea (Risso, 1827) and Aristeus antennatus (Risso, 1816), from the north-western Ionian Sea (Mediterranean Sea). Hydrobiologia, 557, 145-154.

Castilho, A. L., Costa, R.C, Fransozo, A., \& Boschi, E. E. (2007). Reproductive pattern of the South American endemic shrimp Artemesia longinaris (Decapoda: Penaeoidea), off São Paulo State, Brazil. Revista de Biología Tropical, 55(1), 39-48.

Castilho, A. L., Furlan, M., Costa, R. C., \& Fransozo, V. (2008). Reproductive biology of the rock shrimp Sicyonia dorsalis (Decapoda: Penaeoidea) from the southeastern coast of Brazil. Invertebrate Reproduction \& Development, 52(1-2), 59-68.

Castilho, A. L., Bauer, R. T., Freire, F. A. M., Fransozo, V., Costa, R. C., Grabowski, R. C., \& Fransozo, A. (2015). Lifespan and reproductive dynamics of the commercially important sea bob shrimp Xiphopenaeus kroyeri (Penaeoidea): Synthesis of a 5-year study. Journal of Crustacean Biology, 35, 30-40. doi: http://dx.doi.org/10.1163/1937240X-00002300

Cha, H. K, Choi, J. H. \& Oh, C. W. (2004). Reproductive biology and growth of the shiba shrimp, Metapenaeus joyneri (Decapoda: Penaeidae), on the western coast of Korea. Journal of Crustacean Biology, 24(1), 93-100.

Chu, K. H., Tam, Y. K., Chung, C. K., \& Ng, W. L. (1993). Morphometric relationships and reproductive maturation of the shrimp, Metapenaeus ensis, from commercial catches in Hong Kong. Fisheries Research, 18, 187-197.

Claverie, T., \& Smith, I. P. (2009). Morphological maturity and allometric growth in the squat lobster Munida rugosa. Journal of the Marine Biological Association of the United Kingdom, 89(6), 1189-1194.

Costa, C. R., \& Fransozo, A. (2004). Reproductive biology of the shrimp Rimapenaeus constrictus (Decapoda, Panaeidae) in the Ubatuba region of Brazil. Journal of Crustacean Biology, 24 (2), 274-281.

Demestre, M., \& Fortuno, J. M. (1992). Reproduction of the deep-water shrimp Aristeus antennatus (Decapoda: 
Dendrobranchiata). Marine Ecology Progress Series, 84, 41-51.

Díaz, C., Petriella, A. M., \& Fenucci, J. L. (2003). Ciclo de muda y reproducción de la población del langostino Pleoticus muelleri (Crustacea, Penaeoidea) de Mar del Plata. Ciencias Marinas, 29(3), 343-355.

Dineshbabu, A. P., \& Manissery, J. K. (2008). Reproductive biology of ridgeback shrimp Solenocera choprai (Decapoda, Penaeoidea, Solenoceridae) off Mangalore coast, south India. Fisheries Science, 74, 796-803.

Food and Agriculture Organization of the United Nations (2001). Tropical shrimp fisheries and their impact on living resources. Shrimp fisheries in Asia: Bangladesh, Indonesia and the Philippines; in the Near East: Bahrain and Iran; in Africa: Cameroon, Nigeria and the United Republic of Tanzania; in Latin America: Colombia, Costa Rica, Cuba, Trinidad and Tobago, and Venezuela. FAO Fisheries Circular. No. 974. Rome, Italy: FAO.

Franco, A. R., Ferreira, J. G., \& Nobre, A. M. (2006) Development of a growth model for penaeid shrimp. Aquaculture, 259, 268-277.

Freitas, A. J. (1985). The Penaeoidea of southeast Africa. II: The families Aristeidae and Solenoceridae. Investigational Report of the Oceanographic Research Institute, 57, 1-69.

García, S., \& Le Reste, L. (1986). Ciclos vitales, dinámica, explotación y ordenación de las poblaciones de camarones peneidos costeros. FAO Documentos Técnicos de Pesca, 203, 1-180.

Gautam, K., Nazar, A. R., Anand-Ganesh, E., Mahendran, S., \& Mahadevan, G. (2014). Study of length and weight relationship of Litopenaeus vannamei (Boone, 1931) from east coast of India. International Journal of Science Inventions Today, 3(4), 365-376.

George, M. J., \& Muthu, M. S. (1968). Solenocera waltairensis, a new species of prawn (Decapoda: Penaeidae) from Indian waters. Journal of Marine Biology Association of India, 10, 292-297.

Hammer, Ø., Harper, D. A. T., \& Ryan, P. D. (2001). PAST: Paleontological statistics software package for education and data analysis. Palaeontologia Electronica, $4(1), 9$

Harán, N., Mallo, J., \& Fenucci, J. (2004). Efecto de la densidad sobre el crecimiento y el desarrollo del petasma en langostinos juveniles Pleoticus muelleri (Decapoda, Penaeoidea). Investigaciones Marinas, 32(1), 11-18

Hendrickx, M. (1995). Camarones. In W. Fischer, F. Krupp, W. Schneider, C. Sommer, K. E. Carpenter, \& V. H. Niem (Eds.). Guía FAO para la identificación de especies para los fines de pesca. Pacífico centrooriental (pp. 417-537). Roma, Italy: FAO.
Hernáez, P., Rombenso, A., Pinheiro, M. A. A., \& Simões, N. (2012). Population structure and sexual maturity of the calico box crab Hepatus epheliticus Linnaeus (Brachyura, Hepatidae) from Yucatan Peninsula, Mexico. Latin American Journal of Aquatic Research, 40(2), 480-486. doi: 10.3856/vol40-issue2-fulltext-25

Hernández-Noguera, L., Soto-Rojas, R., \& Canales-Ramírez, C. (2016). Reproducción del camarón carabalí Trachypenaeus byrdi (Burkenroad, 1934) en la parte interna del Golfo de Nicoya, Costa Rica. Revista de Ciencias Marinas y Costeras, 8(1), 79-93.

Hilborn, R., Branch, T. A., Ernst, B., Magnusson, A., Minte-Vera, C. V. Scheuerell, M. D., \& Valero, J. L. (2003). State of the world's fisheries. Annual Review of Environment and Resources, 28, 359-399.

Hoang, T., Lee, S. Y., Keenan, C. P., \& Marsden, G. E. (2002). Observations on growth, sexual maturity and spawning performance of pond-reared Penaeus merguiensis. Aquaculture Research, 33, 863-873.

Holthuis, L. B. (1980). Shrimps and prawns of the world. An annotated catalogue of species of interest to fisheries. FAO Fisheries Synopsis, 125, 1-271.

Jackson, J. B. C., Kirby, M. X., Berger, W. H., Bjorndal, K. A., Botsford, L. W., Bourque, B. J., Warner, R. R. (2001). Historical overfishing and the recent collapse of coastal ecosystems. Science, 293, 629-638.

King, M. (2007). Fisheries Management, in Fisheries Biology, Assessment and Management. Oxford, United Kingdom: Blackwell Publishing. doi: 10.1002/9781118688038.ch6

Leal-Gaxiola, A., López-Martínez, J., Chávez, E. A., Hernández-Vázquez, S., \& Méndez-Tenorio, F. (2001). Interannual variability of the reproductive period of the brown shrimp, Farfantepenaeus californiensis (Holmes, 1900) (Decapoda, Natantia). Crustaceana, 74(9), 839-851.

Li, H. Y., Cheng, J. H., \& Li, S. F. (2012). Reproductive biology and growth of the deep-water shrimp Solenocera melantho in the east China Sea. Journal of Shellfish Research, 31(3), 841-846. doi: "http://dx.doi. org/10.2983/035.031.0331"

López-Martínez, J., Rábago-Quiroza, C., Nevárez-Martínez, M. O., García-Juárez, A. R., Rivera-Parra, G., \& Chávez-Villalba, J. (2005). Growth, reproduction, and size at first maturity of blue shrimp, Litopenaeus stylirostris (Stimpson, 1874) along the east coast of the Gulf of California, Mexico. Fisheries Research, $71,93-102$

MacDiarmid, A. B., \& Saint-Marie, B. (2006). Reproduction. In B. Phillips (Ed.). Lobsters: Biology, Management, Aquaculture and Fisheries (pp. 45-77). Oxford, United Kingdom: Blackwell Publishing. doi: 10.1002/9780470995969.ch2 
McQuaid, N., Briggs, R. P., \& Roberts, D. (2006). Estimation of the size of onset of sexual maturity in Nephrops norvegicus (L.). Fisheries Research, 81(1), 26-36. doi: 10.1016/j.fishres.2006.06.003

Morato, T., Watson, R., Pitcher, T. J., \& Pauly, D. (2006). Fishing down the deep. Fish and Fisheries, 7(1), 24-34.

Muggeo, V. M. R. (2008). Segmented: an R package to fit regression models with broken-line relationships. $R$ News, 8(1), 20-25.

Norse, E. A., Brooke, S., Cheung, W. W. L., Clark, M. R., Ekeland, I., Froese, R., Gjerde, K. M., Haedrich, R. L., Heppell, S. S., Morato, T., Morgan, L. E., Pauly, D., Sumaila, R. U., \& Watson, R. (2012). Sustainability of deep-sea fisheries. Marine Policy, 36, 307-320.

Ohtomi, J., \& Irieda, S. (1997) Growth of the deep-water mud shrimp Solenocera melantho de Man, 1907 (Decapoda, Penaeoidea, Solenoceridae) in Kagoshima Bay, southern Japan. Crustaceana, 70(1), 45-58.

Ohtomi, J., Yamamoto, S., \& Koshio, S. (1998). Ovarian maturation and spawning of the deep-water mud shrimp Solenocera melantho De Man, 1907 (Decapoda, Penaeoidea, Solenoceridae) in Kagoshima Bay, southern Japan. Crustaceana, 71(6), 672-685.

Palter, J., León-Coto, S., \& Ballestero, D. (2007). The distribution of nutrients, dissolved oxygen and chlorophyll a in the upper Gulf of Nicoya, Costa Rica, a tropical estuary. Revista de Biología Tropical, 55(2), 427-436.

Paramo, J., Pérez, D., \& Wolff, M. (2014). Reproducción del camarón rosado Farfantepenaeus notialis (Decapoda: Penaeidae) en el Caribe colombiano. Revista de Biología Tropical, 62(2), 513-521.

Pardal-Souza, A. L., \& Pinheiro, M. A. A. (2013). Relative growth and reproduction in Achelous spinicarpus (Crustacea: Portunidae) on the south-eastern continental shelf of Brazil. Journal of the Marine Biological Association of the United Kingdom, 93(3), 667-674.

Paschoal, L. R. P., Guimarães, F. J., \& Couto, E. C. G. (2016). Growth and reproductive biology of the amphidromous shrimp Palaemon pandaliformis (Decapoda: Caridea) in a Neotropical river from northeastern Brazil. Zoologia, 33(6): 1-14. doi: 10.1590/ S1984-4689zool-20160060

Pauly, D., Christensen, V., Guénette, S., Pitcher, T. J., Sumaila, U. R., Walters, C. J., Watson, R., \& Zeller, D. (2002). Towards sustainability in world fisheries. Nature, 418, 689-695. doi: 10.1038/ nature 01017

Pérez-Farfante, I. (1981). Solenocera alfonso a new species of shrimp (Penaeoidea: Solenoceridae) from the
Philippines. Proceedings of the Biological Society of Washington, 94, 631-639.

Pérez-Farfante, I., \& Bullis, H. R. (1973). Western Atlantic shrimps of genus Solenocera with description of a new species (Crustacea: Decapoda: Penaeidae). Smithsonian Contribution to Zoology, 153, 1-33.

Pérez-Farfante, I., \& Grey, D. L. (1980). A new species of Solenocera (Crustacea: Decapoda: Solenoceridae) from northern Australia. Proceedings of the Biological Society of Washington, 93, 421-434.

Polidoro, B. A, Livingstone, S. R., Carpenter, K. E., Hutchinson, B., Mast, R. B., Pilcher, N., Sadovy de Mitcheson, Y., \& Valenti, S. (2008). Status of the world's marine species. In J. C. Vié, C. Hilton-Taylor \& S. N. Stuart (Eds.). The 2008 Review of the IUCN Red List of Threatened Species (pp. 1-7). Gland, Switzerland: IUCN.

Puentes, V., Madrid, N., \& Zapata, L. A. (2007). Catch composition of the deep sea shrimp fishery (Solenocera agassizi Faxon, 1893; Farfantepenaeus californiensis Holmes, 1900 and Farfantepenaeus brevirostris Kingsley, 1878) in the Colombian Pacific Ocean. Gayana, 71, 84-95.

Queirós, A. N., Weetman, A., McLay, H. A., \& Dobby, H. (2013). Geographical variation in size at the onset of maturity of male and female Norway lobster Nephrops norvegicus (L., Homarida: Decapoda) in Scottish waters. Fisheries Research, 139, 132-144.

R Development Core Team (2014). R: A language and environment for statistical computing. Vienna, Austria: R Foundation for Statistical Computing. Retrieved form http://www.R-project.org/

Ramírez-Llodra, E. (2002). Fecundity and Life-history Strategies in Marine Invertebrates. Advances in Marine Biology, 43, 87-170.

Ramírez-Llodra, E. R., Tyler, P. A., Baker, M. C., Bergstad, O. A., Clark, M. R., Escobar, E., ... Van Dover, C. L. (2011). Man and the last great wilderness: human impact on the deep sea. PLoS ONE, 6(7), 1-25. doi:10.1371/journal.pone.0022588

Roa, R., Ernst, B., \& Tapia, F. (1999). Estimation of size at sexual maturity: an evaluation of analytical and resampling procedures. Fisheries Bulletin, 97, 570-580.

Rodríguez, A., Rueda, M., \& Cubillos, L.A. (2012). Agregación reproductiva del camarón de aguas profundas Solenocera agassizi (Crustacea: Decapoda) en el Pacífico Colombiano. Boletín de Investigaciones Marinas y Costeras, 41, 429-446.

Instituto Costarricense de Pesca y Acuicultura. (n.d.). Sección de estadística pesquera . Retrieved from https:// www.incopesca.go.cr/publicaciones/estadisticas.html 
Sala Constitucional (07 de agosto 2013) Sentencia No 2013-10540 [MP Fernando Castillo Víquez]

Segura, A. M., \& Delgado, E. A. (2012). Size at sexual maturity and growth of the red shrimp Pleoticus muelleri (Decapoda: Penaeoidea) captured artisanally in the Atlantic coast of Uruguay. Pan-American Journal of Aquatic Sciences, 7(3), 125-134.

Sobrino, I., \& García, T. (2007). Reproductive aspects of the rose shrimp Parapenaeus longirostris (Lucas, 1846) in the Gulf of Cadiz (southwestern Iberian Peninsula). Boletín Instituto Español de Oceanografia, 23(1-4), 57-71.

Stuhldreier, I., Sánchez-Noguera, C., Rixen, T., Cortés, J., Morales, A., \& Wild, C. (2015) Effects of seasonal upwelling on inorganic and organic matter dynamics in the water column of Eastern Pacific coral reefs. PLOS ONE, 10(11): e0142681. doi:10.1371/journal. pone. 0142681

Tabash, B. F. A., \& Palacios, V. J. A. (1996). Stock assessment of two penaeid prawn species, Penaeus occidentalis and Penaeus stylirostris (Decapoda: Penaeidae), in Golfo de Nicoya, Costa Rica. Revista de Biología Tropical, 44(2), 595-602.

Tabash-Blanco, F. A. (2007). Explotación de la pesquería de arrastre de camarón durante el período 1991-1999 en el Golfo de Nicoya, Costa Rica. Revista de Biología Tropical, 55(1), 207-218.

Tirmizi, N. M. (1958). A study of some developmental stages of the thelycum and its relation to the spermatophores in the prawn Penaeus japonicus Bate. Proceedings of the Zoological Society of London, 131, 231-244.

Trujillo, P., Cisneros-Montemayor, A. M., Harper, S., \& Zeller, D. (2012). Reconstruction of Costa Rica's marine fisheries catches (1950-2008). Fisheries Centre Working Paper Series, 2012-03, 1-21.

Villalobos-Rojas, F., \& Wehrtmann, I. S. (2011). Gonad development in the commercially exploited deepwater shrimp Solenocera agassizii (Decapoda: Solenoceridae) from Pacific Costa Rica, Central America. Fisheries Research, 109, 150-156. doi: 10.1016/j. fishres.2011.01.032

Villalobos-Rojas, F., \& Wehrtmann, I. S. (2014). Secondary sexual characters and spermatophores of Solenocera agassizii (Decapoda: Solenoceridae), including a comparison with other solenocerid shrimp. Sexuality and Early Development in Aquatic Organisms, 1, 45-55. doi: $10.3354 /$ sedao00006

Wehrtmann, I. S., \& Echeverría-Sáenz, S. (2007). Crustacean fauna (Stomatopoda, Decapoda) associated with the deepwater fishery of Heterocarpus vicarius (Decapoda, Pandalidae) along the Pacific coast of Costa Rica. Revista de Biología Tropical, 55(1), 121-130.

Wehrtmann, I. S., \& Nielsen-Muñoz, V. (2009). The deepwater fishery along the Pacific coast of Costa Rica, Central America. Latin American Journal of Aquatic Research, 37(3), 543-554.

Wehrtmann I. S., Arana, P. M., Barriga, E., Gracia, A., \& Pezzuto, P. R. (2012). Deep-water shrimp fisheries in Latin America: a review. Latin American Journal of Aquatic Research, 40(3), 497-535.

Xu, L., Yang, F., Abula, A., \& Qin, S. (2013). A parametric bootstrap approach for two-way ANOVA in presence of possible interactions with unequal variances. Journal of Multivariate Analysis, 115, 172-180. doi:10.1016/j.jmva.2012.10.008

Zar, J. H. (1999). Biostatistical Analysis. New Jersey, USA: Prentice-Hall. 